\title{
Penerapan Model Pembelajaran Kooperatif Tipe Think Pair and Share Untuk Meningkatkan Prestasi Belajar Matematika
}

\author{
I Ketut Suwela ${ }^{*}$ \\ ${ }^{1}$ SD Negeri 1 Sukadana, Indonesia
}

\section{A R T I C L E I N F O}

Article history:

Received 12 October 2020

Received in revised form

30 November 2020

Accepted 10 January 2021

Available online 01

February 2021

\section{Kata Kunci:}

Tipe Think Pair and Share,

Prestasi Belajar

Keywords:

Tipe Think Pair and Share

learning achievement.

\begin{abstract}
A B S T R A K
Penelitian ini dilatarbelakangi oleh rendahnya hasil belajar Pendidikan Matematika siswa kelas IV Sekolah Dasar Negeri. Sebagian besar siswa belum mencapai ketuntasan minimal pada pelajaran pendidikan Matematika. Penelitian ini bertujuan mengkaji efektivitas model kooperatif tipe Thinsk Pair and Share terhadap Prestasi belajar matematika siswa. Penelitian ini merupakan PenelitianTindakan Kelas (PTK), yang dilaksanakan dalam 2 siklus. Subyek dalam penelitian ini siswa kelas IV Sekolah Dasar Negeri sebanyak 30 orang. Analisis data dalam penelitian ini menggunakan deskriftif kuantitatif. Hasil penelitian menunjukkan hasil belajar siswa pada siklus I skor rata-rata hasil belajar dengan kategori rendah. Nilai rata-rata hasil belajar siswa pada siklus I yaitu 64,83 dengan ketuntasan klasikal $64,83 \%$, daya serap $70 \%$. Kemudian pada siklus II mengalami peningkatan, rata-rata hasil belajar menjadi 75,33 ketuntasan klasikal menjadi $75,33 \%$ dan daya serap menjadi $100 \%$. Dan hasil analisis hasil belajar siklus I dan II mengalami peningkatan nilai rata-rata hasil belajar sebesar 10,5 ketuntasan klasikal sebesar $30 \%$ daya serap sebesar $10,5 \%$ dengan penerapan pembelajaran kooperatif tipe think pair and share. Jadi, penerapan pembelajaran kooperatif tipe think pair and share dapat meningkatkan prestasi belajar Pendidikan Matematika.
\end{abstract}

A B S T R A K

This research is motivated by the low learning outcomes of Mathematics Education for fourth grade students of State Elementary Schools. Most students have not yet reached the minimum completeness in Mathematics education. This study aims to examine the effectiveness of the think pair and share cooperative model on students' mathematics learning achievement. This research is a Classroom Action Research (CAR), which was carried out in 2 cycles. The subjects in this study were 30 grade students of State Elementary Schools. Analysis of the data in this study using quantitative descriptive. The results showed that the students' learning outcomes in the first cycle had an average score of learning outcomes in the low category. The average value of student learning outcomes in the first cycle is 64.83 with $64.83 \%$ classical completeness, $70 \%$ absorption. Then in the second cycle there was an increase, the average learning outcome became 75.33 classical completeness to $75.33 \%$ and the absorption capacity became $100 \%$. And the results of the analysis of learning outcomes in cycles I and II experienced an increase in the average value of learning outcomes by 10.5 classical completeness by $30 \%$ absorption by $10.5 \%$ with the application of cooperative learning type think pair and share. So, the application of the think pair and share type of cooperative learning can improve the learning achievement of Mathematics Education.

\section{Pendahuluan}

Matematika adalah salah satu mata pelajaran yang sangat penting dalam kehidupan siswa, matematika tidak bisa dipisahkan karena segala aktivitas anak tidak terlepas dari matematika. Pelajaran

Copyright (๔) Universitas Pendidikan Ganesha. All rights reserved 
matematika menjadi pelajaran yang cukup penting bagi siswa mengingat penerapannya dapat berlangsung bukan hanya dalam konteks lingkungan sekolah melainkan dalam masyarakat juga (Theresia, 2018). Matematika sebagai sarana dalam mengembangkan pola pikir ilmiah, logis, analitis, dan sistematis (Dewi \& Agustika, 2020; Nasrulloh, 2017). Pembelajaran matematika memberikan kempaan memecahkan masalah yang dihadapi oleh siswa dalam kehidupannya sehari-hari (Tanjung \& Nababan, 2018). Pentingnya matematika mengharusakan guru mengembangkan pembelajaran yang inovatif agar menurangi pendapat siswa yang berpikir bawa matematika itu sulit. Pembelajaran matematika bukanlah pembelajaran yang mudah, banyak pendapat bahwa matematika merupakan mata pelajaran yang sulit. Masalah yang lain adalah miskonsepsi, satu masalah yang sering dihadapi oleh murid dalam pembelajaran matematika dan sering menjadi penghalang untuk memahami konsep- konsep matematika (Wardani et al., 2016). Kondisi ini senada dengan hasil observasi awal yang dilakukan dimana pada kenyataanya, guru matematika mengalami kesulitan dalam mengaktifkan siswa secara merata karena kemampuan yang dimiliki oleh setiap siswa tidaklah sama. Oleh karena itu, hanya siswa yang memiliki kemampuan tinggi yang menguasai kelas, sedangkan siswa lainnya pasif, dan persentase siswa pasif lebih banyak daripada siswa yang aktif. Hal itu berdampak pada hasil belajar siswa yang secara klasikal belum memenuhi KKM yang ditargetkan. Hal seperti itu terjadi pada siswa kelas IV Sekolah Dasar Negeri 1 Sukadana. Aktivitas siswa dalam kegiatan pembelajaran cenderung hanya menyimak dan mencatat. Kalau pun ada hal-hal yang kurang jelas, hanya beberapa siswa yang mau bertanya. Hal Akhirnya, pada saat diberikan tes, hasilnya secara klasikal berada di bawah KKM, yakni 60,00 padahal KKM-nya adalah 65. Pada akhirnya, hal tersebut akan berimplikasi pada aktivitas belajar siswa yang optimal dan hasil belajar siswa sesuai harapan. Keberhasilan siswa dalam proses pembelajaran di sekolah ditunjukkan dengan prestasi belajar yang dicapai merupakan akumulasi dari beberapa faktor yang satu dengan yang lainnya saling berkaitan. Proses pembelajaran di sekolah bersifat komplek, karena di dalamnya terdapat aspek pedagogik, psikologis dan didaktik. Untuk mengatasi masalah tersebut maka diperlukan pembelajaran yang memebrikan kesempatan siswa untuk belajar menemukan pengetahuanya sendiri (Yerizon et al., 2020).

Keberhasilan proses pembelajaran dapat diukur dengan perubahan pengetahuan, sikap dan keterampilan siswa setelah melakukan proses belajar, yang lebih dikenal dengan istilah hasil belajar. Untuk menghujudkan hasil belajar yang sesaui dengan tujuan pembelajaran maka diperlukan model pembelajaran. Salah satu model pembelajaran yang digunakan adalah kooperatif tipe think pair and share (TPS). TPS memberikan kesempatan kepada siswa untuk bekerja sendiri dan bekerja sama dengan orang lain, serta saling berdiskusi untuk mengungkapkan ide antar teman sebaya (Kusuma \& Aisyah, 2012; Nasrulloh, 2017). TPS dapat memberi siswa lebih banyak waktu berpikir, untuk merespon dan saling membantu (Dharmayanti et al., 2017; Marta, 2017). TPS siswa akan terlatih berpikir dengan baik dan dapat meningkatkan kemampuan siswa menyampaikan pendapat dan menghargai pendapat orang lain (Mariana \& Riwayati, 2016). Pembelajaran dengan model TPS akan memberikan kesempatan kepada siswa untuk berinteraksi dengan teman sebayanya (Maryoto, 2018). Adanya TPS dalam pembelajaran akan memberikan suasana yang bervariatif dalam proses diskusi (Andika et al., 2016) dan disesuaikan dengan karakteristik anak SD.

Penelitian yang dilakukan oleh Dharma et al., (2019) menghasilkan bahwa penerapan model pembelajaran TPS meningkatkan kemampuan komunikasi matematis serta percaya diri peserta didik kelas X MIPA 1 SMA Negeri 6 Semarang tahun pelajaran 2018/2019. Nataliasari, (2014) menunjukkan bahwa 1) Think: pembelajaran menggunakan TPS memberikan kesempatan kepada siswa berpikir secara mandiri, (2) Pair: selama proses pembelajaran secara berkelompok mendorong siswa mempunyai daya nalar yang tinggi dan kreatif dalam menyelesaikan soal-soal yang diberikan, (3) Share: kegiatan ini mampu memberikan kepuasan tersendiri dan rasa percaya diri dalam diri siswa. Rosita \& Leonard, (2015) menunjukkan bahwa terdapat pengaruh metode pembelajaran TPS (Think Pair Share) terhadap hasil belajar matematika. Supatni et al., (2015) menunjukkan bahwa terdapat pengaruh model pembelajaran kooperatif tipe Think Pair Share terhadap hasil belajar IPA siswa kelas VI SD Gugus Letda Made Putra Tahun Ajaran 2014/2015. Jadi, model TPS memberikan pengaruh yang positif terhadap pembelajaran. Sehingga, model pembelajaran ini dijadikan salah satu solusi yang bisa digunakan dalam mengatasi rendahnya hasil belajar matematika siswa. Penelitia tindakan kelas ini bertujuan untuk mengkaji efektivitas model pembelajaran think pair share terhadap prestasi belajar siswa. Adanya model pembelajaran ini akan membantu guru dalam menciptakan suasana pembelajaran yang menarik dan lebih menyenangkan, yang tentunya akan berdampak terhadap hasil belajar siswa.

\section{Metode}

Rancangan yang digunakan dalam penelitian ini adalah penelitian tindakan kelas (PTK). Penelitian ini dilakukan secara bertahap atau memakai siklus. Setiap siklus terdiri atas beberapa tahapan 
meliputi: perencanaan tindakan, pelaksanaan tindakan, observasi/evaluasi, dan refleksi untuk menentukan rencana tindakan pada siklus selanjutnya Penelitian ini lebih memfokuskan pada masalah yang dikaji dan proses refleksi. Rasional dari pendekatan action researchlebih disandarkan pada jenis data dan fokus masalah yang akan dikaji dalam penelitian yaitu penomena didaktik metodik yang berintikan pada dinamika sosial yang menuntut sejumlah data dan verivikasi kejadian. Melalui penelitian tindakan diharapkan dapat mendorong dan dapat membangkitkan guru agar memiliki kesadaran diri melakukan refleksi diri terhadap kinerja profesionalnya untuk peningkatan sosial di lingkungannya. Jadi secara garis besarnya penelitian ini dilakukan melalui refleksi diri dengan tujuan untuk memperbaiki kinerja sehingga motivasi dan hasil belajar siswa meningkat. Dalam penelitian tindakan kelas terdapat langkah-langkah penelitian yang direncanakan dalam bentuk siklus yang memungkinkan terjadinya kerja kelompok ataupun kerja mandiri secara intensif. Sesuai dengan hal itu penelitian tindakan kelas itu dilaksanakan secara bertahap dan multi siklus untuk mendapatkan hasil yang terbaik dalam hal ini data yang valid. Setiap siklus yang ada tentunya terdiri atas refleksi awal, kemudian disusul oleh rencana tindakan, pelaksanaan tindakan, observasi/evaluasi dan refleksi. Subyek dalam penelitian ini siswa kelas IV Sekolah Dasar Negeri 1 Sukadana tahun pelajaran 2019/2020 sebanyak 30 orang. Metode pengumpulan data yang digunkan adalah lembar observasi dan tes hasil belajar. Analisis data dalam penelitian ini menggunakan deskriftif kuantitatif dengan menghitung mean dan persentase ketuntasan tiap siklus penelitian. Secara rinci pelaksanaan penelitian dapat disimak pada deskripsi masing-masing siklus. Rencana waktu pelaksanaan tindakan siklus I terlihat pada Tabel 1.

Tabel 1. Jadwal Pelaksanaan Penelitian Tindakan Siklus I

\begin{tabular}{lllll}
\hline NO & Hari/Tanggal & Jam Pertemuan & SK/KD & PosTes/Tes Akhir \\
\hline 1 & Senin, 5 Agustus 2019 & 3 x 35 Menit & 2.1 & Tindakan I \\
2 & Senin,12 Agustus 2019 & 3x 35 Menit & 2.2 & Tindakan II \\
3 & Senin,19 Agustus 2019 & 3 x 35 Menit & & Tes akhir siklus I \\
\hline
\end{tabular}

\section{Hasil dan Pembahasan}

Sebelum melaksanakan siklus I terlebih dahulu diawali dengan observasi. Untuk mengetahui kemampuan awal yang dimiliki siswa dalam pembelajaran Matematika. Berdasarkan hasil observasi, dapat di ketahui bahwa kemampuan siswa dalam pembelajaran Matematika masih rendah. Setelah dilakukan observasi lebih lanjut, dapat disimpulkan bahwa faktor penyebab rendahnya hasil belajar siswa itu disebabkan oleh masih kurang aktifnya siswa dalam pembelajaran serta metode mengajar yang dipergunakan oleh guru masih belum mampu mengoptimalkan aktivitas dan prestasi belajar siswa. Siswa merasa jenuh dalam belajar, minat belajar siswa rendah dan berujung pada hasil belajar siswa kelas IV SD Negeri 1 Sukadana menjadi rendah. Oleh karena itu dipandang perlu dilaksanakan tindakan untuk memperbaiki hasil belajar siswa. Tindakan tersebut adalah dengan mengujicobakan pembelajaran kooperatif tipe think pair and share.

\section{Siklus I}

Pelaksanaan siklus I dilakukan sesuai dengan rencana yang dirancang. Siklus I ini dilaksanakan selama 3 kali pertemuan, yang terdiri atas pelaksanaan tindakan siklus I sebanyak 2 kali pertemuan, dan tes akhir siklus I dilaksanakan dalam 1 kali pertemuan. Siklus I ini dilaksanakan dalam empat tahapan yakni, perencanaan, pelaksanaan tindakan, observasi/evaluasi dan refleksi. Sebelum melakukan tindakan, adapun persiapan-persiapan yang perlu dilakukan untuk kelancaran pelaksanaan tindakan. Dalam siklus I, dilakukan beberapa tahap yaitu tahap perencanaan tindakan I, pelaksanaan tindakan I, Observasi dan evaluasi I, serta tahap refleksi yang dilaksanakan pada akhir siklus oleh peneliti. Mencermati pelaksanaan siklus secara keseluruhan, dapat ditegaskan bahwa telah terjadi peningkatan yang cukup signifikan, baik rata-rata hasil belajar, daya serap maupun ketuntasan klasikal. Hasil analisis pada pelaksanaan tindakan siklus I menunjukkan nilai rata- rata yang diperoleh siswa sebesar 68,83 sedangkan daya serap siswa sebesar 64,83\% dan ketuntasan klasikal sebesar $70 \%$. Hal itu berarti bahwa hasil yang diperoleh oleh siswa pada siklus I masih belum sesuai dengan target yang ditetapkan yaitu ketuntasan klasikal sebesar 75\%. Hasil analisis ini ditunjukkan pada Gambar 1. 


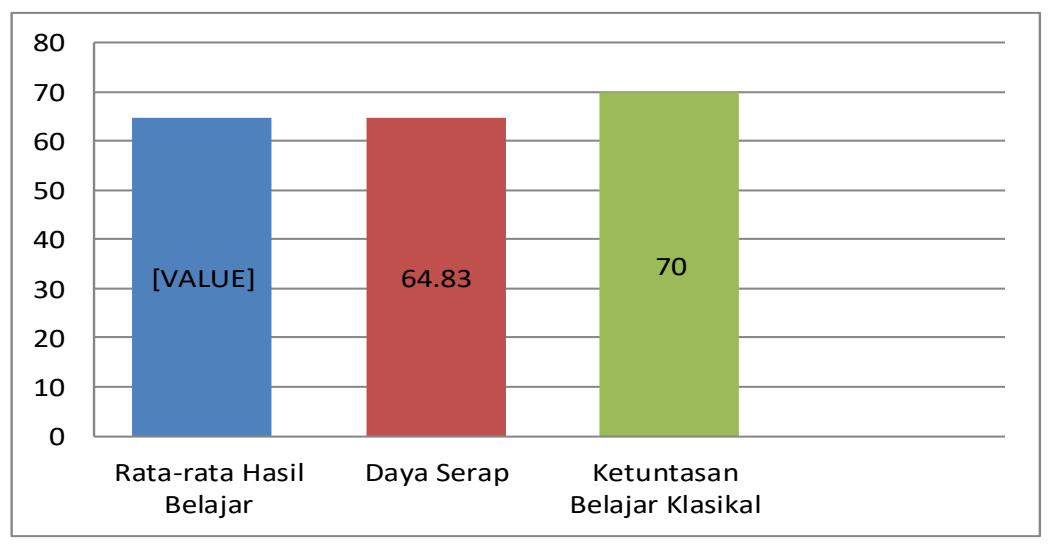

Gambar 1. Grafik Data Hasil Belajar Siklus I

Refleksi ini dilakukan setelah siklus I selesai. Refleksi dilakukan berdasarkan observasi dan evaluasi yang sudah dilakukan. Refleksi ini dilakukan untuk mengetahui kelemahan-kelemahan dan keunggulan-keunggulan pada pelaksanaan tindakan tersebut. Kelemahan- kelemahan dan keunggulan keunggulan pada pelaksanaan tindakan tersebut. Kelemahan- kelemahannya akan dijadikan dasar dalam memperbaiki pelaksanaan pada siklus berikutnya. Sementara itu, keunggulannya akan tetap dipertahankan agar dapat mencapai hasil yang optimal dalam pelaksanaan tindakan tersebut. Kelemahankelemahannya akan dijadikan dasar dalam memperbaiki pelaksanaan tindakan pada siklus berikutnya. Sementara itu, keunggulannya akan tetap dipertahankan agar dapat mencapai hasil yang optimal dalam pelaksanan tindakan tersebut. Berikut ini akan dibicarakan Pertama ada beberapa kelemahan yang menyebabkan hasil belajar siswa masih di bawah kriteria keberhasilan. Sesungguhnya, peneliti tidak menemukan kendala yang berarti dalam pelaksanaan penelitian ini, ada beberapa hal yang menjadi fokus perhatian peneliti, yaitu 1) beberapa siswa masih belum mampu mempergunakan waktu yang diberikan secara efektif dalam memecahkan persoalan/menjawab pertanyaan yang diajukan guru ( kurang fokus) , 2) saat proses diskusi berpasangan dengan teman sebangku siswa masih terlihat belum serius 3) siswa kurang berkonsentrasi dengan penjelasan guru, 4) saat presentasi hasil hasil diskusi siswa masih terlihat kikuk. Keunggulan dari pelaksanaan siklus I adalah suasana kelas terasa lebih hidup karena siswa yang sebelumnya kurang aktif dalam pembelajaran mulai lebih aktif karena ada motivasi dalam menampilkan hasil pekerjaannya di depan teman-tamannya. Berdasarkan kelemahan- kelemahan tersebut, maka peneliti akan memperbaiki beberapa langkah dalam pembelajaran. Pada tahap pendahuluan, peneliti akan memberikan arahan kepada siswa agar bisa lebih mempersiapkan diri dalam menerima pelajaran, sehingga saat diberikan pertanyaan bisa dijawab dengan baik. Memberikan motivasi agar saat diskusi berpasangan dengan teman sebangku siswa bisa memanfaatkan waktu dengan baik, agar hasil nya lebih maksimal. Saat presentasi hasil diskusi agar siswa bisa tampil lebih percaya diri.

\section{Siklus II}

Sebagaimana halnya dengan pelaksanaan siklus I, pelaksanaan siklus II dilakukan sesuai dengan rencana yang dirancang dan hasil refleksi siklus I. Siklus II dilakukan selama 3 kali pertemuan, yang terdiri atas pelaksanaan tindakan siklus II sebanyak 2 kali pertemuan dan tes akhir siklus II dilaksanakan dala 1 Kali pertemuan. Siklus II dilaksanakan melalui beberapa tahapan yaitu tahap perencanaan II, tahap pelaksanaan tindakan II, observasi dan evaluasi II, serta refleksi yang dilaksanakan pada akhir siklus oleh peneliti. Berdasarkan perhitungan sebelum dilaksanakan tindakan, maka dapat diperoleh hasil dari siklus II, secara klasikal ketuntasannya sudah mencapai $100 \%$. Hal ini menunjukkan bahwa hasil belajar siswa sudah melebihi kriteria yang ditargetkan dalam penelitian ini. Sementara itu nilai rata- rata yang diperoleh siswa pada siklus II sebesar 75,33 dan daya serap sebesar 75,33\%. Apabila dimasukkan kedalam kategori presentase tingkat penguasaan / daya serap pada table di atas, maka hasil daya serap yang diperoleh siswa kelas IV SD Negeri 1 Sukadana masuk dalam kategori baik. Berdasarkan seluruh hasil belajar diatas berikut tabel perbandingan hasil belajar siklus I dan siklus II. Hasil penelitian siklus II digambarkan pada gambar 2 berikut. 


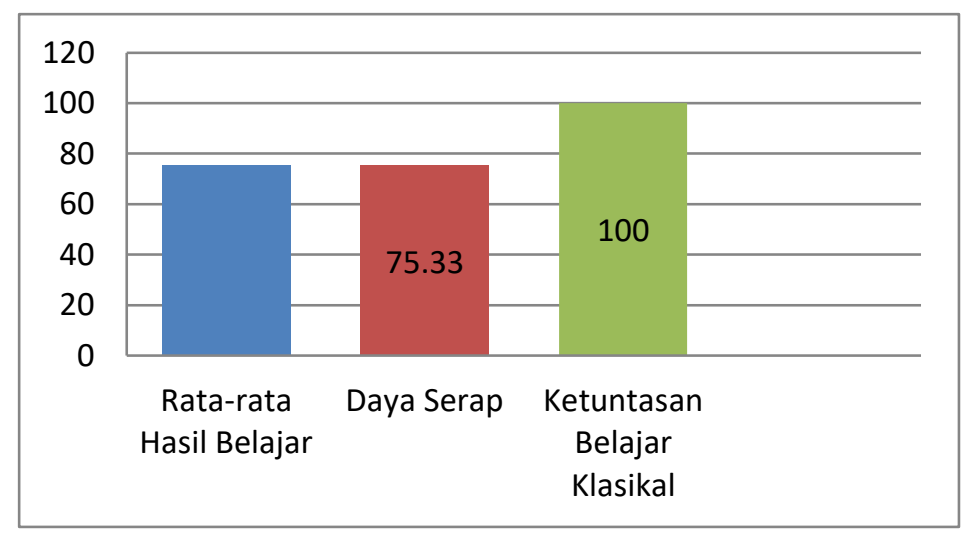

Gambar 2. Grafik Data Hasil Belajar Siklus II

Pada Siklus II terjadi peningkatan rata-rata prestasi belajar siswa menjadi 75,33 dan daya serap juga mengalami peningkatan menjadi 75,33 \%, sedangkan ketuntasan belajar klasikal meningkat menjadi $100 \%$. Meskipun pada evaluasi siklus II masih ada asatuorang siswa yang belum tuntas, tetapi secara ketuntasan klasikal sudah di atas target yang ditetapkan yaitu $85 \%$. Hal ini berarti bahwa kriteria keberhasilan yang ditetapkan peneliti sudah tercapai. Dapat disederhanakan, pada siklus I rata-rata prestasi belajar siswa sebesar 64,83, kemudian siklus II sebesar 75,33. Itu berarti nilai-rata-rata siklus I ke siklus II telah terjadi peningkatan sebesar 10,5. Kemudian daya serap siswa juga mengalami peningkatan dari siklus I dan siklus II. Daya serap siswa pada siklus I sebesar $64,83 \%$ dan pada siklus II sebesar $75,33 \%$. Berdasarkan data tersebut antara siklus I dengan siklus II mengalami peningkatan sebesar 10,5\%. Tidak hanya nilai rata-rata siswa dan daya serap saja yang mengalami peningkatan, ketuntasan klasikal juga meningkat. Pada tahap siklus I terdapat 21 orang siswa yang tuntas dan 9 orang siswa yang tidak tuntas. Selanjunya pada siklus II dari 30 siswa semua tuntas. Berdasarkan data tersebut ketuntasan klasikal siswa pada siklus I ke siklus II terjadi peningkatan sebesar 30\%.

Peningkatan hasil belajar siswa tentunya tidak terlepas dari model pembelajaran yang digunakan, adanya model pembelajaran TPS membuat suasana pembelajaran lebih menarik dan membuat siswa belajar lebih aktif baik secara mandiri maupun secara berkelompok. Siswa belajar dan membangun pengetahuanya sendiri adanya hal ini tentunya akan membuat pembelajaran lebih bermakna. TPS memberikan kesempatan kepada siswa untuk bekerja sendiri dan bekerja sama dengan orang lain, serta saling berdiskusi untuk mengungkapkan ide antar teman sebaya (Kusuma \& Aisyah, 2012; Nasrulloh, 2017). TPS dapat memberi siswa lebih banyak waktu berpikir, untuk merespon dan saling membantu (Dharmayanti et al., 2017; Marta, 2017). TPS siswa akan terlatih berpikir dengan baik dan dapat meningkatkan kemampuan siswa menyampaikan pendapat dan menghargai pendapat orang lain (Mariana \& Riwayati, 2016). Pembelajaran dengan model TPS akan memberikan kesempatan kepada siswa untuk berinteraksi dengan teman sebayanya (Maryoto, 2018). Adanya TPS dalam pembelajaran akan memberikan suasana yang bervariatif dalam proses diskusi (Andika et al., 2016) dan disesuaikan dengan karakteristik anak SD. Beberapa penelitian yang berkaitan dengan model TPS.

Penelitian yang dilakuka oleh Dharma et al., (2019) menghasilkan bahwa penerapan model pembelajaran TPS meningkatkan kemampuan komunikasi matematis serta percaya diri peserta didik kelas X MIPA 1 SMA Negeri 6 Semarang tahun pelajaran 2018/2019. Nataliasari, (2014) menunjukkan bahwa 1) Think: pembelajaran menggunakan TPS memberikan kesempatan kepada siswa berpikir secara mandiri, (2) Pair: selama proses pembelajaran secara berkelompok mendorong siswa mempunyai daya nalar yang tinggi dan kreatif dalam menyelesaikan soal-soal yang diberikan, (3) Share: kegiatan ini mampu memberikan kepuasan tersendiri dan rasa percaya diri dalam diri siswa. Rosita \& Leonard, (2015) menunjukkan bahwa terdapat pengaruh metode pembelajaran TPS (Think Pair Share) terhadap hasil belajar matematika. Supatni et al., (2015) menunjukkan bahwa terdapat pengaruh model pembelajaran kooperatif tipe Think Pair Share terhadap hasil belajar IPA siswa kelas VI SD Gugus Letda Made Putra Tahun Ajaran 2014/2015. Jadi, model TPS memberikan pengaruh yang positif terhadap pembelajaran. Sehingga, model pembelajaran ini dijadikan salah satu solusi yang bisa digunakan dalam mengatasi rendahnya hasil belajar matematika siswa. Peningkatan nilai rata-rata, daya serap, dan ketuntasan 
klasikal dari siklus I dengan siklus II karena penerapan pembelajaran kooperatif tipe think pair and share pada siklus II lebih optimal. Perbaikannya adalah pada tahap pendahuluan, peneliti memberikan arahan kepada siswa agar lebih berkonsentrasi dalam menjawab pertanyaan, lebih mempersiapkan diri dalam menerima pelajaran, bisa memanfaatkan waktu diskusi dengan efektif dan presentasi dengan penuh percaya diri. Oleh karena itu dalam penerapan pembelajaran kooperatif tipe think pair and share hendaknya dilengkapi dengan adanya perhatian yang lebih fokus terhadap siswa.

\section{Simpulan dan Saran}

Berdasarkan hasil penelitian dan pembahasan hasil, maka dapat disimpulkan bahwa penerapan model pembelajaran kooperatif tipe think pair and share dalam pembelajaran Matematika pada siswa kelas IVSekolah Dasar Negeri 1 Sukadana dapat meningkatkan prestasi belajar siswa. Adanya model pembelajaran ini akan membantu guru dalam menciptakan suasana pembelajaran yang menarik dan lebih menyenangkan, yang tentunya akan berdampak terhadap hasil belajar siswa.

\section{Daftar Rujukan}

Andika, N. D., Usodo, B., \& Subanti, S. (2016). Eksperimentasi Model Pembelajaran Kooperatif Tipe Numbered Heads Together ( Nht ) Dan Think Pair Share ( Tps ) Dengan Pendekatan Saintifik Pada Materi Himpunan Ditinjau. Jurnal Elektronik Pembelajaran Matematika, 4(8), 830-840. https://jurnal.uns.ac.id/jpm/article/view/10832.

Dewi, N. P. W. P., \& Agustika, G. N. S. (2020). Efektivitas Pembelajaran Matematika Melalui Pendekatan PMRI Terhadap Kompetensi Pengetahuan Matematika. Jurnal Penelitian Dan Pengembangan Pendidikan, 4(2), 204-214. 2 https://doi.org/jpgsd@upi.edu website:http://ejournal.upi.edu/index.php/jpgsd/index PENERAPAN.

Dharma, I., Pujiastuti, E., \& Harianja, M. (2019). Penerapan Model Pembelajaran TPS (Think-Pair-Share) untuk Meningkatkan Kemampuan Komunikasi Matematis dan Percaya Diri Peserta Didik Kelas X MIPA 1 SMA Negeri 6 Semarang Pada Materi Sistem Persamaan Tiga Variabel Tahun Pelajaran 2018/2019. PRISMA, Prosiding Seminar Nasional Matematika, 2, 239-246. https://journal.unnes.ac.id/sju/index.php/prisma/article/view/28918.

Dharmayanti, N. P., Ardana, I. K., \& Suniasih, N. W. (2017). Pengaruh Model Pembelajaran Kooperatif Tipe Think Pair Share Berbasis Outdoor Study Terhadap Kompetensi Pengetahuan IPA. MIMBAR PGSD Undiksha, 5, 1-10. https://doi.org/http://dx.doi.org/10.23887/jjpgsd.v5i2.10709.

Kusuma, F. W., \& Aisyah, M. N. (2012). Implementasi Model Pembelajaran Kooperatif Tipe Think Pair Share Untuk Meningkatkan Aktivitas Belajar Akuntansi Siswa Kelas Xi Ips 1 Sma Negeri 2 Wonosari Tahun Ajaran 2011/2012. Jurnal Pendidikan Akuntansi Indonesia, 10(2), 43-63. https://doi.org/10.21831/jpai.v10i2.912.

Mariana, P., \& Riwayati. (2016). Perbedaan Hasil Belajar Menggunakan Model Pembelajaran Numbered Heads Together (NHT) Dengan Think Pair Share (TPS) Pada Materi Ekosistem Dikelas VII. Jurnal Pelita Pendidikan, 4(2), 86-92. https://doi.org/https://doi.org/10.24114/jpp.v4i2.4048.

Marta, R. (2017). Peningkatan Hasil Belajar Matematika Dengan Model Kooperatif Tipe Think Pair Share Di Sekolah Dasar. Jurnal Cendekia: Jurnal Pendidikan Matematika, 1(2), 74-79. https://doi.org/10.31004/cendekia.v1i2.24.

Maryoto, G. (2018). Pengaruh Pembelajaran Kooperatif Tipe Think-Pair-Share (Tps) Dan NumberedHeads-Together (Nht) Terhadap Motivasi Dan Hasil Belajar Matematika. Jurnal Pendidikan, 17(2), 121-128. https://doi.org/10.33830/jp.v17i2.271.2016.

Nasrulloh, F. (2017). Keefektifan model kooperatif tipe tps dan nht ditinjau dari prestasi belajar $\begin{array}{llll}\text { matematika siswa } & \text { kelas }\end{array}$ https://doi.org/https://doi.org/10.32764/eduscope.v3i1.181.

Nataliasari, I. (2014). Penggunaan Model Pembelajaran Kooperatif Tipe Think Pair Share (TPS) Untuk Meningkatkan Kemampuan Penalaran Dan Pemecahan Masalah Matematis Siswa MTS. Jurnal Pendidikan Dan Keguruan, 1(1), 209670. https://doi.org/10.23887/jjpgsd.v5i2.10655.

Rosita, I., \& Leonard, L. (2015). Meningkatkan Kerja Sama Siswa Melalui Pembelajaran Kooperatif Tipe Think Pair Share. Formatif: Jurnal Ilmiah Pendidikan MIPA, 3(1), 1-10. 
https://doi.org/10.30998/formatif.v3i1.108.

Supatni, N. M., Dantes, N., Tika, I. N., Studi, P., Pendidikan, E., \& Pascasarjana, P. (2015). Pengaruh Model Pembelajaran Think Pair Share ( Tps ) Terhadap Prestasi Belajar Matematika Dengan Kovariabel Kemampuan Numerik Siswa Kelas Vi Di Sd Gugus Ii Bedulu. E-Journal Program Pascasarjana Universitas Pendidikan Ganesha, 5(1), 1-9. https://doi.org/http://dx.doi.org/10.23887/jjpgsd.v3i1.5800.

Tanjung, H. S., \& Nababan, S. A. (2018). Pengembangan Perangkat Pembelajaran Matematika Berorientasi Model Pembelajaran Berbasis Masalah (PBM) Untuk Meningkatkan Kemampuan Berpikir Kritis Siswa SMA Se Kuala Nagan Raya Aceh. GENTA MULIA, IX(2), 56-70. https://ejournal.stkipbbm.ac.id/index.php/gm/article/view/168.

Theresia, E. (2018). Studi Deskriptif mengenai Self Concept dalam Pelajaran Matematika pada Siswa Kelas V SD "X" di Kota Bandung. Humanitas (Jurnal Psikologi), 1(3), 161. https://doi.org/10.28932/humanitas.v1i3.754.

Wardani, E. P., Mardiyana, M., \& Subanti, S. (2016). Analisis Miskonsepsi Siswa Pada Materi Pokok Lingkaran Ditinjau Dari Kesiapan Belajar Dan Gaya Berpikir Siswa Kelas Xi Ipa Sma N 3 Surakarta Tahun Ajaran 2013/2014. Jurnal Pembelajaran Matematika, 4(3), 328-340. https://jurnal.ugm.ac.id/jpsi/article/download/6955/5416.

Yerizon, Y., Putri, Y. U., Musdi, E., \& Permana, D. (2020). Efektivitas Perangkat Pembelajaran Matematika Berbasis Pendekatan Contextual Teaching and Learning Terhadap Kemampuan Komunikasi Matematis. AKSIOMA: Jurnal Program Studi Pendidikan Matematika, 9(1), 205. https://doi.org/10.24127/ajpm.v9i1.2305. 